\title{
THE TEACHER'S ROLE IN ORGANIZING THE EFFECTIVE INTERACTION OF SECONDARY SCHOOLS, OUT-OF-SCHOOL EDUCATIONAL ESTABLISHMENTS AND A FAMILY IN THE PROCESS OF JUNIOR PUPILS' MORAL DEVELOPMENT
}

\section{Holovska Iryna ${ }^{1}$}

DOI: https://doi.org/10.30525/978-9934-571-89-3_11

The main task of education in the XXI century is the upbringing of the next generation, which could realize the complex socio-cultural situation and build its relations with the outside world on the basis of mutual understanding, cooperation and tolerance. The representatives of such generation should possess moral virtues to be able to value their own freedom, respect the freedom of others and treat each other as equals.

Secondary school is recognized as being a leading institution in the process of junior pupils' moral development. But it is important to mention that without the unity of efforts of different social institutions the effectiveness of this process will be low. An optimal environment for the imitation and the guided practice of moral conduct should be created in the triad "secondary schools - out-of-school educational establishments - a family".

Different aspects of the interaction between educational institutions and a family are discussed in the researches conducted by $T$. Vinohradova, K. Zhurba, T. Kravchenko, N. Kniazeva, L. Povaliy, V. Postovyi, I. Sidanych, O. Khromova etc. Scientific papers of O. Aliksiichuk, O. Bezverkhyi, S. Bilozerska, I. Komanovskyi, O. Matviienko, O. Romanenko are devoted to the process of junior pupils' moral development. Few researches have addressed the problem of the teacher's role in creating the optimal environment for pupils' moral development.

The purpose of this article is to outline the role of a primary school teacher in organizing the effective interaction of secondary schools, out-of-school educational establishments and a family in the process of junior pupils' moral development, and to define the principles and methods of it.

Family is the primary unit of a society and the main source of its spiritual, economic and social development. Functions of the family are extremely noble and diverse. For a child, the family becomes the environment where he receives his first knowledge about the surrounding world, relationships between people, where the first skills and habits are developed. Moral values, which are formed in the family circle, become the basis of the child's world outlook, moral benchmarks and a vital position.

However, in spite of the significant influence of a family on the formation of the child's personality, the tasks of moral education can not be solved only by its efforts. The actual problems of upbringing can be solved by the teaching staff as teachers are competent professionals who have pedagogical and psychological knowledge about

\footnotetext{
${ }^{1}$ Communal Higher Educational Establishment

"Vinnytsia Humanitarian and Pedagogical College", Ukraine 
the age and psychological peculiarities of junior pupils. Cooperation with the teachers of out-of-school educational establishments will allow to understand the world of the child's interests better, to reveal his inclinations and talents, to create an optimal environment for the formation of moral virtues. That is why it is very important to combine the opportunities and efforts of all the social institutions in junior pupils' development.

In our opinion, the leading role in this process should belong to the primary school teachers. T. Vinohradova notes that the interaction of all above mentioned social institutions first of all should be based on the child's needs. She also points out that the interests of every family should be taken into account $[1$, p. 4]. N. Knyazeva, in particular, highlights the problems in relations between educational institutions and families: a big gap between the parents' psychological and pedagogical culture and modern educational technologies; parents' complexes and fears etc. [2, p. 58-59]. The literature review shows that a number of problems are identified in the process of organizing the effective interaction of educational establishments and a family. The most important among them are: teachers' fears about too active parental interference in the school's educational process; parents' fears that the school will set standards that do not coincide with the traditions of a particular family etc. [5, p. 45; 6, p. 79].

L. Nazarenko sees the ways of solving these problems in involving parents in cooperation with educational institutions on a partnership basis. The scientist distinguishes its forms: active, constructive, passive and destructive [3, p. 34]. We believe that the integration of the efforts should be organized on the basis of democratic relations between all the participants of the educational process. The analysis of psychological and pedagogical literature allowed us to distinguish the main features of this process, such as collegiality of joint work, encouragement of initiative, recognition of the right to express different points of view on a particular problem, search of joint decisions, development of relations on the basis of cooperation, dialogue, mutual respect and responsibility.

In our opinion, interaction of secondary schools, out-of-school educational establishments and a family in the process of junior pupils' moral development should be based on the following principles:

1. The principle of harmonization of moral values. Teachers and parents should define the common system of values.

2 . The principle of the unity of requirements.

3 . The principle of systematicity and consistency.

4. The principle of equal partnership. The interests and needs of all the participants of the educational process should be taken into account in the planning of educational work.

5. The principle of differentiated approach. Teachers should pay attention to parents' age, their individual characteristics and their level of pedagogical preparation.

6. The principle of priority of trust. It means that cooperation with parents should be organized on the basis of sincere respect for them, regardless of their social status. It will help to establish trusting relationships between teachers and a family. 
7. The principle of humanism. The child's personality is in the center of educational process.

8. The principle of voluntariness. Parents are free to participate in the educational work and to cooperate with the teaching staff.

Based on these principles, we can identify the following tasks to be implemented in the process of interaction of secondary schools, out-of-school educational establishments and a family: 1) the development and implementation of common requirements for junior pupils in educational institutions and families; 2) raising the parents' pedagogical culture; 3 ) the implementation of psychological and pedagogical assistance in solving the problems of family education; 4) parents involvement in joint activities with children.

To accomplish the tasks, it is necessary to determine the ways of interaction, to select effective forms and methods of cooperation. The use of traditional forms, the effectiveness of which has been proven by many years of school practice, is justified. These forms can be conventionally divided into three groups: individual (individual pedagogical conversation, pedagogical counseling etc.), group (group discussion, group counseling), mass (lectures and conversations, questions and answers evenings, disputes, meetings at the "round table", meeting-concerts).

However, the results of pedagogical studies indicate that the use of only traditional forms and methods of organizing the interaction of teaching staff and parents is not effective in solving the problems of junior pupils' moral development. That is why Ukrainian scholars and leading educators are actively searching for effective, innovative forms of interaction with parents, which can include: "pedagogical landing", "in the family circle", "the day of good deeds", "family box", "chamber folk" etc. [4, p. 26-27]. The leading role in this process belongs to the primary school teachers, since they are specially trained specialists who possess the necessary psychological and pedagogical knowledge for effective organization of the process of moral education of schoolchildren and establishing cooperation with other educational institutions. The following functions are assigned to them in this process: 1) integration; 2) coordination; 3) development; 4) protection; 5) correction.

Thus, secondary schools, out-of-school educational establishments and families are the most important social centers responsible for creating an optimal environment for the junior pupils' moral development. However, their educational activities will be successful when they will be true allies and partners in this field and will adhere to a single outlet in the process of moral education.

\section{References:}

1. Vinohradova T. (2006). Vzaiemodiia batkiv ta pedahohiv - neobkhidna umova dlia vykhovannia novoho pokolinnia [Interaction of Parents and Teachers - a Necessary Condition for the Education of a New Generation]. Zavuch, no. 8, March, p. 4.

2. Knyazeva N. (2002). Vzaimodejstvie uchrezhdenij dopolnitelnogo obrazovaniya s semyoj v nravstvennom vospitanii detej doshkolnogo vozrasta [Interaction of institutions of additional education with the family in the moral upbringing of children of preschool age] ( $\mathrm{PhD}$ Thesis), Moscow. 
3. Nazarenko L. (2005). Shliakhy rozvytku vzaiemodii simi ta shkoly [Ways of development of interaction between family and school]. Education path, no. 1, pp. 33-37.

4. Yuzefik L., Kupina N. (order) (2002). Orhanizatsiia roboty z batkamy [Organization of work with parents]. Ternopil: Aston.

5. Kay W. Moral education. A social study of the influence of society home and school. London, $1975,167 \mathrm{p}$. 